\title{
Prognostic value of MMP-7-181 A/G single nucleotid polymorphism and helicobacter pylori infection in gastric cancer
}

\section{Mide kanserinde MMP-7 geni -181 A/G tek nükleotid polimorfizminin ve H. Pylori enfeksiyonu’ nun prognostik önemi}

\author{
Erdinc Yolcun ${ }^{1}$, Volkan Oter $^{2}$, Serdar Oter $^{3}$, Salim Demirci' ${ }^{4}$, Ali Ekrem Unal ${ }^{4}$, Güvem Gümüş \\ Akay $^{5}$, Ajlan Tukun ${ }^{6}$
}

\author{
${ }^{1}$ Karaman Tıp Merkezi, Genel cerrahi Kliniği, Karaman, Türkiye \\ ${ }^{2}$ Sakarya Üniversitesi, Gastroenteroloji Cerrahi Bilim Dalı, Türkiye \\ ${ }^{3}$ Mersin Üniversitesi, Gastroenteroloji Cerrahi Bilim Dalı, Türkiye \\ ${ }^{4}$ Ankara Üniversitesi, Cerrahi Onkoloji Bilim Dalı, Türkiye \\ ${ }^{5}$ Ankara Üniversitesi, Beyin Araştırma Merkezi, Türkiye \\ ${ }^{6}$ Ankara Üniversitesi, Medikal Genetik Bilim Dalı, Türkiye
}

GíRiş ve AMAÇ: Mide Kanseri halen yüksek morbidite ve mortaliteye neden olmaktadır. Bu sebepten araştırmacılar, prognozu etkileyen faktörleri araştırmaya yönelmiş̧lerdir.

Çalışmamızda Mide Kanseri tanısı ile opere olan tümör ve normal doku örnekleri kullanılarak MMP-7 polimorfizminin ve H. Pylori enfeksiyonunun Mide Kanseri’nin prognozuna etkisi araştırılmıştır.

YÖNTEM ve GEREÇLER: Ekim 2008 - Ekim 2010 tarihleri arasında Ankara Üniversitesi Tip Fakültesi hastanesi, Cerrahi Onkoloji Departmanı'ndan mide adenokarsinomu olan vakalar içinde 50 kişi rastgele seçildi ve sağlıklı kontrol grubu da 50 kişiden oluşturuldu. Çalışma grubu 31 erkek ve 19 kadın olmak üzere 50 kişiden oluşmaktadır. Mide Kanser'li 50 hastanın; 15'inin (\%30) AA, 20'sinin (\%40) AG, 15'inin (\%30) GG genotipine sahip olduğu, sağlıklı gönüllülerde ise 25' i AG, 9' u GG and 16's1 AA genotipine sahip olduğu bulundu.

BULGULAR: G1+G2 ile G3 evreleri A/G polimorfizmine göre karşılaştıııldığında G3 evrede G Allel sıklığının $\% 53.8 \mathrm{G} 1+\mathrm{G} 2$ evrelerde \%45.8 bulunmuştur. Bu sonuç da G Allel sıklığının fazla olmasının Grade'i arttırdığını düşündürmüştür. Hastalar H. Pylori taşımalarına göre Tümör Boyutu ile karşılaştırıldığında T1+T2 evreye sahip olanların $\% 0$ oranında H. Pylori $(+)$ olduğu T3+T4 olanların \%65.1 oranında H.Pylori $(+)$ olduğu bulunmuştur $(\mathrm{p}=0.02)$. Bu durum, H. pylori'nin mide kanseri için negatif bir prognostik faktör olduğu yönündeki daha önce yapılmış çalışmaları desteklemiştir.

TARTIŞMA ve SONUÇ: Bu çalışma da, Türk toplumundaki sağlıklı gönüllülerin A alleli sıklığı $=\% 57, \mathrm{G}$ alleli sıklğ $1=\% 43$ olarak saptandı. Bu durumun Avrupa'daki G allel frekansı ile paralellik gösterdiği bulundu. Ülkemizde ve Avrupa'da mide kanseri prognozu Japonya'dan daha kötüdür, çünkü G allel frekansı Japonya'dan daha fazladır.

Anahtar Kelimeler: Mide kanseri, Matrix metalloproteinase 7, prognoz, H. Pylori

\footnotetext{
ABSTRACT

INTRODUCTION: Gastric Cancer is still causes high morbidity and mortality. So the researchers directed to research the factors affecting prognosis.

In our present study, the effects of both MMP7 -181G>A promoter polymorphism and H. pylori infection on gastric cancer prognosis was investigated in gastric adenocarcinoma.

METHODS: All of the cases $(n=50)$ and healthy controls $(n=50)$ were unrelated individuals who were selected from the Ankara University School of Medicine, Department of Surgical Oncology between October 2008 and October 2010. The study group consisted of 50 patients, including 31 males and 19 females, including 15=AA, $20=\mathrm{AG}, 15=\mathrm{GG}$ genotype. In the control group; $25=\mathrm{AG}, 9=\mathrm{GG}$ and 16=AA genotype was found.
} 
RESULTS: $\mathrm{G} 1+\mathrm{G} 2$ and $\mathrm{G} 3$ phases were compared according to $\mathrm{A} / \mathrm{G}$ polymorphism. $\mathrm{G}$ allele frequency of stage $\mathrm{G} 3=53.8 \%$ of patients with $\mathrm{G} 1+\mathrm{G} 2$ phase was found $45.8 \%$. According to this result; the frequency of $\mathrm{G}$ allele being considered to increase the $G$ phase. Patients compared with H.Pylori and tumor size, in stage $\mathrm{T} 1+\mathrm{T} 2$ no patients had $\mathrm{H}$ pylori $(+)$, in $\mathrm{T} 3+\mathrm{T} 4,65.1 \%$ of those with $\mathrm{H}$ pylori $(+)$ was found $(\mathrm{p}=0.02)$. This situation proved previously conducted studies that $\mathrm{H}$. pylori is a negative prognostic factor for gastric cancer.

DISCUSSION AND CONCLUSION: In this study healthy volunteers population was found the frequency of A allele $=\% 57$, frequency of allele $\mathrm{G}=43 \%$, this condition is found to be parallel with the European's $\mathrm{G}$ allele frequency. In our country and in Europe stomach cancer prognosis is worse than Japan because frequency of $G$ allele is more than Japan.

Keywords: gastric cancer, MMP-7, prognosis, Helicobacter Pylori

\section{INTRODUCTION}

Gastric Cancer is widely seen all over the world, despite advances of surgery it is still a very serious health problem that causes high morbidity and mortality. Currently the main treatment method of this disease is surgery. 5year disease-free survival of gastric cancer is very low so the researchers directed to research the factors affecting prognosis(1). Similar to all other solid tumors, genetic and environmental factors play an important role in gastric cancer development and progression. Previous studies have clearly demonstrated that multiple genetic alterations are responsible for the development and progression of gastric cancer.(2)

Matrix metalloproteinase 7 (MMP7), also known as matrilysin, is located on chromosome 11 and it is the MMP with smallest structure (3). Matrilysin found excessively in human cancer tissues and its production is associated with cancer progression.Tumor formation is a multi-step process that involves cell growth, invasion, metastasis and angiogenesis. It has been shown that matrilysin plays an important role in several biochemical processes like degradation and destruction of extracellular matrix (ECM) proteins as well as destruction, activation and modification of non-ECM proteins (3).

MMP7 is a member of the MMP family that expressed from polarized glandular epithelium for organization of the defense against microbial colonization in stomach and gastrointestinal system (4). Therewithal, MMP-7 overexpressed in gastric malignancy and affects cell proliferation and apoptosis (57). Epithelial cells of gastrointestinal system, urogenital system and respiratory system are frequently exposed to bacterias. Maintenance of constitution and function of normal epithelium is provided by proliferation, migration and apoptosis of epithelial cells, in relation with immune system (cytokine secretion, chemokine, antigen presentation)

It has been shown that Helicobacter pylori ( $H$. pylori) infection also cause susceptibility to gastric cancer. This situation is known as tumorigenesis that facilitated by bacteria $(8,9)$. The role of $H$. pylori and MMP7 in the progression of cancer is still not clear.

In our present study, the effects of both MMP7 -181G>A promoter polymorphism and $H$. pylori infection on gastric cancer prognosis was investigated in gastric adenocarcinoma.

\section{MATERIAL and METHODS}

All of the cases $(n=50)$ and healthy controls $(n=50)$ were unrelated individuals who were selected from the Ankara University Hospital, Department of Surgical Oncology between October 2008 and October 2010. The case group comprised tumor resection inpatients who were histopathologically confirmed to have gastric adenocarcinoma. Tissue samples were obtained after receiving the patients' informed consent granting permission for anonymous use of their tissue samples in future studies. This study was performed in accordance with the principles of the Declaration of Helsinki and was approved by the Research Ethics Committee of Ankara University Faculty of Medicine (approval\# 17372). The patients had no family history of cancer and were free of concurrent malignant conditions other than gastric cancer. None of the patients had received chemotherapy or radiotherapy prior to surgery. If the lesions were considered as early gastric cancer during surgical resection, the patients were excluded from the study. Patients who were diagnosed with diffuse type gastric adenocarcinoma during histopathological evaluation were excluded from the study and only patients with 
the intestinal type of gastric adenocarcinoma were enrolled. Tumoral and normal mucosa samples were obtained from all the subjects. Samples of normal mucosa were collected from areas near the surgical margins and far from the tumors that were macroscopically free of tumor invasion. Routine histopathological examinations and $H$. pylori infection status were performed at the Department of Pathology, Faculty of Medicine, Ankara University, Ankara, Turkey.

Peripheral blood samples obtained from 50 volunteers admitted to outpatient clinic of general surgery for reasons except malignancy were included in the study as control group.

\section{DNA Isolation from Tissue and Peripheral Blood Samples}

DNA samples were obtained from approximately $0.5 \mathrm{~cm}^{3}$ freshly frozen tissue specimens stored at $80^{\circ} \mathrm{C}$. DNA extraction was performed DNA isolation from solid tissue specimen was performed by using BDtract Genomic DNA Isolation Kit (40001, Maxim Biotech, CA, USA) according to the manufacturer's instructions. NucleoSpin ${ }^{\circledR}$ Blood XL (Macherey Nagel, 740 950. 50) kit was used for DNA isolation from pheripheral blood samples.

$\begin{array}{llcc}\begin{array}{l}\text { Genotyping of } \\ \text { polymorphism }\end{array} & \text { MMP7 } & -\mathbf{1 8 1 A}>\boldsymbol{G} \\ \mathrm{MMP7}-181 \mathrm{~A}>\mathrm{G} & \text { genotyping was done by }\end{array}$
PCR-RFLP method. The PCR of G2677T/A polymorphism was performed in a total volume of $25 \mu \mathrm{l}$, using $100 \mathrm{ng}$ of genomic DNA with 10 pmol primers each (F: 5'TGGTACCATAATGTCCTGAATG -3', R: 5'TCGTTATTGGCAGGAAGCACACAATGA

ATT -3'(Sugimoto ve ark., 2008), $0.2 \mathrm{mM}$ of each dNTP, $1 \times$ buffer with $\mathrm{KCl}, 3 \mathrm{mM}$ of $\mathrm{MgCl} 2$ and 1U Taq DNA polymerase (Fermantas, EP 0402). The cycling conditions performed in a Techne TC-4000 Thermal Cycler (Bibby Scientific Limited, Staffordshire, UK) were as follows: amplification consisted of a five-minute denaturation step at $95^{\circ} \mathrm{C} ; 35$ cycles, $30 \mathrm{~s}$ at $95^{\circ} \mathrm{C}, 30 \mathrm{~s}$ at $60^{\circ} \mathrm{C}$ and $30 \mathrm{~s}$ at $72^{\circ} \mathrm{C}$; and a seven-minute final extension at $72^{\circ} \mathrm{C}$, followed by cooling to $4^{\circ} \mathrm{C}$. Genotype analysis was conducted using RFLP. Restriction digestion was performed in a total volume of $25 \mu \mathrm{l}$ reaction mixture containing $10 \mu \mathrm{l}$ PCR product and $20 \mathrm{U}$ EcoRI restriction endonuclease.
Reaction mixtures were incubated at $37^{\circ} \mathrm{C}$ overnight and the digested PCR products were resolved by electrophoresis in 3\% agarose gels containing $0.5 \mu \mathrm{g} / \mathrm{ml}$ of ethidium bromide and visualized by KODAK Gel Logic 200 image analyzing system. A allele: $150 \mathrm{bp} ; \mathrm{G}$ allele: $120 \mathrm{bp}+30 \mathrm{bp}$.

Statistical Analysis In statistical analysis, allele frequencies were tested with chi-square test, and genotype frequencies were tested with Wilcoxon signed rank test. P values less than 0.05 were taken to indicate a statistically significant difference.

\section{RESULTS}

The demographic and clinicopathological characteristics of the patients are summarized in Table 1. Of the patients, 31 were men and 19 were women, with a mean age of $58,5( \pm$ 3,46 ) years, respectively. $86 \%$ of the patients were diagnosed at late stages (T3 and T4) and $64 \%$ of the patients had lymph node metastasis. $8 \%$ of the patients patient had a distant metastasis. Well-differentiated tumors were detected in $40 \%$ of the patients, whereas $60 \%$ of the patients had poorly differentiated tumors. $H$. pylori infection was positive in $54 \%$ of our patients. It is shown that, 27 of 40 patients $(67 \%)$ with $\mathrm{T} 3$ tumor were H.pylori $(+)$, there were no H. pylori (+) patients in T1 and T2 tumors. Fourteen of 25 patients (56\%) who were H.pylori (-), had N0, 11 had tumors with lymph node metastasis. Sixteen of 26 patients (61\%) who were H.pylori (+) had G3, $10(38 \%)$ had G1 and $3(1 \%)$ had G2 tumors. It seems that $\mathrm{H}$. pylori negativity was higher in $\mathrm{T} 1$ and T2 patients while H.pylori positivity is higher in T3 patients. H.pylori negativity was higher in G1 stage while H. Pylori positivity was higher in $\mathrm{G} 2$ and $\mathrm{G} 3$ stages.

The allele and genotype distributions of the MMP7 -181 A>G SNP in the patients and controls are summarized in Table 2. Of the patients, $15(30 \%)$ have AA, $20(40 \%)$ have AG and 15 (30\%) have GG genotype. There was no genotypic difference acoording to MMP7 - 181 A/G between cancerous and noncancerous tissues ( $p>0.05$ ). The $\mathrm{A}$ and $\mathrm{G}$ allele frequencies were found $50 \%$ each. In the control group, 25 volunteers $(50 \%)$ have AG, 9 volunteers (18\%) have GG and 16 volunteers (32\%) have AA genotype. . The frequency of the A allele was calculated as $57 \%$ and the 
frequency of the $\mathrm{G}$ allele was found as $43 \%$ in the control group. When T3 group evaluated in itself, $32.5 \%$ have AA, $42.5 \%$ have AG and $25 \%$ have GG genotype.

Table 1. distribution of gastric cancer patients according to tumor size (T) and lymph node status (N)

\begin{tabular}{|c|c|c|c|c|}
\hline & Frequency & Percent & $\begin{array}{c}\text { Current } \\
\text { Percent }\end{array}$ & $\begin{array}{c}\text { Cumulative } \\
\text { Percent }\end{array}$ \\
\hline T1 & 4 & 8,0 & 8,0 & 8,0 \\
T2 & 3 & 6,0 & 6,0 & 14,0 \\
T3 & 40 & 80,0 & 80,0 & 94,0 \\
Total & 50 & 6,0 & 6,0 & \\
\hline N0 & 18 & 36,0 & 36,0 & 36,0 \\
N1 & 13 & 26,0 & 26,0 & 62,0 \\
N2 & 12 & 24,0 & 24,0 & 86,0 \\
N3 & 7 & 14,0 & 14,0 & 100,0 \\
Total & 50 & 100,0 & 100,0 & 100,0 \\
\hline
\end{tabular}

It is seem that $\mathrm{G}$ allele frequency is higher in patients with gastric cancer. The high frequency of $\mathrm{G}$ allele in $\mathrm{G} 2$ and $\mathrm{G} 3$ stages suggests that $G$ allele carriers have worser prognosis. $\mathrm{G}$ allele frequency was higher in $\mathrm{T} 4$ tumor size.

Table 2. Comparison of the tumor size, grade and lymph node Involvement in H. Pylori (+) and (-) patients

\begin{tabular}{|c|c|c|}
\hline & H. Pylori (+) & H. Pylori (-) \\
\hline T2 & 0 & 3 \\
\hline T3 & 27 & 13 \\
\hline T4 & 1 & 2 \\
\hline G1 & 7 & 12 \\
\hline G2 & 3 & 1 \\
\hline G3 & 16 & 11 \\
\hline N0 & 6 & 14 \\
\hline N1 & 8 & 4 \\
\hline N2 & 8 & 3 \\
\hline N3 & 3 & 4 \\
\hline
\end{tabular}

(T: Tumor size, G:Grade, N: Lymph Node Status)

When $\mathrm{T} 1+\mathrm{T} 2+\mathrm{T} 3$ tumor size compared with patients with T4 tumor size, it was found that $\mathrm{G}$ allele frequency was $83.3 \%$ in $\mathrm{T} 4$ patients in comparison to $47.9 \%$ in $\mathrm{T} 1+\mathrm{T} 2+\mathrm{T} 3$ patients. However, the the difference did not reach the statistical significance $(\mathrm{p}=0,204)$. The $\mathrm{G}$ allele frequency value of $83.3 \%$, suggests that this clinical significance could be statistically significant when number of subjects increased.

When $\mathrm{G} 1+\mathrm{G} 2$ and $\mathrm{G} 3$ stages compared according to MMP7 -181 A>G SNP, G allele frequency was $53.8 \%$ in $\mathrm{G} 3$ and $45.8 \%$ in $\mathrm{G} 1+\mathrm{G} 2$ stages. While this result suggests that high frequency of $G$ allele increase $G$ stage, $p$ value was 0.423 after Chi-square test was performed. However, the the difference did not reach the statistical significance. .

When tumor size of patients compared with $\mathrm{G}$ genotype carriage, $100 \%$ of T4 patients were $\mathrm{G}$ carriers $(\mathrm{AG}+\mathrm{GG})$ while $68.1 \%$ of $\mathrm{T} 1+\mathrm{T} 2+\mathrm{T} 3$ patients were $\mathrm{G}$ carriers and it was thought that $\mathrm{G}$ genotype increase tumor size, clinically. However, the the difference did not reach the statistical significance $(\mathrm{p}=0.545)$ When $\mathrm{M} 0$ and $\mathrm{M} 1+\mathrm{Mx}$ metastasis status compared according to MMP7 -181 A $>\mathrm{G}$ genotype, $\mathrm{G}$ allele carrier frequency (AG $+\mathrm{GG}$ ) were $66.7 \%$ in $\mathrm{M} 0$ patients while $78.6 \%$ in $\mathrm{M} 1+\mathrm{Mx}$ patients. However, the the difference did not reach the statistical significance $(\mathrm{p}=0,507)$.

When H.Pylori status compared according to tumor size, $0 \%$ of patients with $\mathrm{T} 1+\mathrm{T} 2$ stage had $\mathrm{H}$. Pylori (+) while $65.1 \%$ of patients with $\mathrm{T} 3+\mathrm{T} 4$ stage had H.Pylori (+) (Table 3).

\section{DISCUSSION}

MMPs are zinc-dependent proteinases which are capable of breaking down many ECM proteins (10While MMPs play role in biological processes like tissue remodeling, wound healing, and embryonic development,they also have role in tumor invasion and metastasis by destruction of connective tissue, basal membrane and stromal matrix. MMP-7 is called as matrilysin. Besides a large proteolytic activity it is also involved in the activation of other MMPs (10).

It is known that MMP-7 expression is elevated in many cancer types such as colorectal, gastric, esophageal, pancreas, prostate, head, neck, lung, liver and breast. Furthermore, MMP-7 levels increase in premalignant lesions of colon adenomas, pancreas, stomach, breast and prostate. 
MMPs are generally expressed from normal tissues but on the contrary MMP-7 expressed mainly from tumoral cells. It has been shown that MMP-7 leads cancer progression by destruction of ESM and additionally inhibiting apoptosis of cancer cells, decreasing cell adhesions and increasing angiogenesis (10).

Table 3. Clinicopathologic Evaluation of MMP-7 -181 A / G Polymorphism

\begin{tabular}{ccccccccccc}
\hline SNP & Group & Number & \multicolumn{2}{c}{ Allele } & & N & & Genotype & \\
& & & & & & & & & & \\
\hline $\mathbf{- 1 8 1}$ & & & A & G & p & & AG & GG & AA & p \\
$\mathbf{A} / \mathbf{G}$ & & & & & & & & & & \\
\hline & $\begin{array}{l}\text { Contol } \\
\text { group }\end{array}$ & 100 & 57 & 43 & - & 50 & 25 & 9 & 16 & \\
& & $57 \%$ & $43 \%$ & & & $50 \%$ & $18 \%$ & $32 \%$ & \\
& & & & & & & & & \\
& $\begin{array}{l}\text { Gastric } \\
\text { cancer } \\
\text { patients }\end{array}$ & 100 & 50 & 50 & - & 50 & 20 & 15 & 15 & \\
\hline
\end{tabular}

Tumor Size

$\mathrm{T} 1+\mathrm{T} 2+\mathrm{T} 3(\mathrm{n}=94)$

$\begin{array}{ccc}49 & 45 & \mathrm{p}>0.05\end{array}$

$\mathrm{T} 4(\mathrm{n}=6)$

$\% 52.1 \quad \% 47.9$

$\% 16.7 \quad \% 83.3$

\section{Grade}

$\mathrm{G} 1+\mathrm{G} 2(\mathrm{n}=44)$

$\mathrm{G} 3(\mathrm{n}=46)$

$\begin{array}{ccc}26 & 22 & \mathrm{p}>0.05 \\ \% 54.2 & \% 45.8 & \\ 24 & 22 & \\ \% 46.2 & \% 53.8 & \end{array}$

\section{Lymph node invasion}

$\mathrm{N} 0(\mathrm{n}=36)$

$\begin{array}{ll}0.50 & 0.50 \\ 0.50 & 0.50\end{array}$

$\begin{array}{rrr}6 & 6 & 6 \\ \% 33 & \% 33 & \% 33 \\ 14 & 9 & 9 \\ \% 43 & \% 28 & \% 29\end{array}$

$\mathrm{N} 1+\mathrm{N} 2+\mathrm{N} 3(\mathrm{n}=64)$

\section{Metastasis}

M0

$\mathrm{M} 1+\mathrm{MX}$

\section{$A G+G G$}

24(\%66.7)

$11(\% 78.6)$

\section{AA}

$12(\% 33.3) \quad \mathrm{p}>0.05$

$3 \% 21.4$

\begin{tabular}{lccc}
\hline H Pylori & H Pylori $\quad(-)$ & H Pylori $(+)$ & \\
$\mathrm{T} 1+\mathrm{T} 2(\mathrm{n}=7)$ & 7 & 0 & $\mathrm{p}<0.05$ \\
& $\% 100$ & $\% 0$ & \\
$\mathrm{~T} 3+\mathrm{T} 4(\mathrm{n}=43)$ & 15 & 28 & \\
& $\% 34.9$ & $\% 65.1$ & \\
\hline
\end{tabular}

$\mathrm{SNP}=$ Single Nucleotide Polymorphism

In a study investigating the prognostic significance of MMP-7 in gastric cancer, stomach tissues obtained from patients operated because of gastric cancer were stained immunohistochemically and MMP-7 signal intensity was compared with patients tumor size, lymph node metastasis and distant metastasis rates and as a result, more lymph node metastasis and distant metastasis rates were found in patients with higher MMP-7 
levels and this was adversely affecting survival (10). On the basis of this results, it has been shown that MMP-7 is an independent predictor of survival in gastric cancer.

In our study, when $\mathrm{T} 1+\mathrm{T} 2+\mathrm{T} 3$ tumor size compared with patients with $\mathrm{T} 4$ tumor size, it was found that $G$ allele frequency was $83.3 \%$ in $\mathrm{T} 4$ patients in comparison to $47.9 \%$ in $\mathrm{T} 1+\mathrm{T} 2+\mathrm{T} 3$ patients. Carrying $\mathrm{G}$ allele is thought to increase the size of the tumor. P value was 0.204 ( $p>0.05)$ when the results were evaluated by Chi-square test. The $\mathrm{G}$ allele frequency value of $83.3 \%$, suggests that this clinical significance could be statistically significant when number of subjects increased.

When tumor size of patients compared with $\mathrm{G}$ genotype carriage, $100 \%$ of T4 patients were $G$ carriers $(A G+G G)$ while $68.1 \%$ of $\mathrm{T} 1+\mathrm{T} 2+\mathrm{T} 3$ patients were $\mathrm{G}$ carriers and it was thought that $G$ genotype may be correlated with increase tumor size, clinically. Although $p$ value is 0.545 , it is expected that this relationship could be statistically significant when number of subjects increased.

The risk of gastric cancer increases in gastric epithelial cells exposed to H.pylori infection for a long time (11-12). When H.Pylori status compared according to tumor size, $0 \%$ of patients with $\mathrm{T} 1+\mathrm{T} 2$ stage had $\mathrm{H}$. Pylori (+) while $65.1 \%$ of patients with T3+T4 stage had H.Pylori (+) (Table 3). When this results evaluated with Chi-Square test $p$ value was 0.02 and significant relationship found between H.Pylori positivity and tumor size and this results support the proposal in Chin $\mathrm{Wu}$ et al. study (13) that "H. pylori is a negative prognostic factor for gastric cancer".

It has recently shown that MMP-7-181 A/G polymorphism is associated with poor prognosis in gastric cancer (14). In a study that Sugimoto et al. performed about relation between MMP-7 polymorphism and susceptibility to gastric cancer with progression of gastric cancer, they found about MMP-7- $181 \mathrm{~A} / \mathrm{G}$ polymorphism that; $83.1 \%$ of cases had AA, $16.9 \%$ had AG and $0 \%$ had GG genotype. They found that MMP-7-181 G allele carriers relatively have serious risk for development and poor prognosis of gastric cancer considering A allele carriers (15) (OR, $2.32 ; 95 \% \mathrm{CI}, 1: 24$ to $4: 35)$. When clinical stages of the patients evaluated, it has been shown that $G$ allele carriers have significantly increased risk for Stage 3-4 cancer (OR, 3.66; 95\% CI, 1.54-8.73). In our study, when G1+G2 and G3 stages compared according to $\mathrm{A} / \mathrm{G}$ polymorphism, $\mathrm{G}$ allele frequency was $53.8 \%$ in $\mathrm{G} 3$ and $45.8 \%$ in $\mathrm{G} 1+\mathrm{G} 2$ stages. While this result suggests that high frequency of $\mathrm{G}$ allele increase $\mathrm{G}$ stage, $p$ value was 0.423 after Chisquare test was performed. No significant relationship considered because $\mathrm{p}$ value was $>0.05$. However, it is also expected that this relationship could be statistically significant when number of subjects increased.

A previously performed study revealed that $\mathrm{A} / \mathrm{A}$ allele carriers have better prognosis and less distant metastasis rate than $\mathrm{G} / \mathrm{G}$ allele carriers (16). In our study, when M0 and $\mathrm{M} 1+\mathrm{Mx}$ metastasis status compared according to $\mathrm{G}$ allele carriage, $\mathrm{AG}+\mathrm{GG}$ rate were $66.7 \%$ in M0 patients while $78.6 \%$ in $\mathrm{M} 1+\mathrm{Mx}$ patients. Carriage of $\mathrm{G}$ allele can lead to distant metastasis clinically but $\mathrm{p}$ value was 0.507. High rate of $\mathrm{M} 1+\mathrm{Mx}$ patients suggests that this relationship could be statistically significant when number of subjects increased.

Another study showed differences in MMP-7-181 A/G polymorphism for different ethnic groups. MMP-7-181 G allele was found in $41.1 \%$ of the Europeans and between $2.8 \%$ and $6 \%$ in the East Asians. Therefore the difference of MMP-7-181 A/G polymorphism in this groups has thought to be the reason of why gastric cancer has different development rates in different ethnic groups (17). In our study, A allele frequency was $57 \%$ and $\mathrm{G}$ allele frequency was $43 \%$ in healthy volunteers and results found to be similar to the $G$ allele frequency detected in Europeans. The poor prognosis of gastric cancer in our counrty and Europe than Far East countries was thought to be due to higher rate of $\mathrm{G}$ allele frequency.

In a study conducted by M. Honda and his friends, cancerous and non-cancerous tissues of 48 gastric cancer patients were compared after operation and immunohistochemical expression of MMP-7 and mRNA measurement was performed. Study results revealed that, in $41(87 \%)$ of 48 patients, MMP-7 expression and mRNA were higher in cancerous mucosa than normal mucosa. Additionally in patients with overexpression of MMP-7 in cancerous tissues; a significant relation was found in terms of excessive gastric wall invasion, more lymphatic spread and more vascular invasion. 
They suggest that these findings strongly support the hypothesis that MMP-7 expression increases tumor invasion. (18). Based on this study, we compared cancerous and noncancerous tissues of 50 gastric cancer patients with RFLP in our study but we did not find any difference between cancerous and noncancerous tissues that will generate MMP-7$181 \mathrm{~A} / \mathrm{G}$ changes in DNA level.

In conclusion; the healthy volunteers population was found the frequency of $\mathrm{A}$ allele $=\% 57$, frequency of allele $\mathrm{G}=43 \%$, this condition is found to be parallel with the European's $\mathrm{G}$ allele frequency. In our country and in Europe stomach cancer prognosis is

\section{REFERENCES}

1. Stock M, Otto F. Gene deregulation in gastric cancer. Gene. 2005;360:1-19.

doi: 10.1016/j.gene.2005.06.026.

2. Zheng L, Wang L, Ajani J, Xie E. Molecular basis of gastric cancer development and progression. Gastric Cancer. 2004;7:61-77. doi: 10.1007/s10120-004-0277-4

3. Masanorı I1,1 Hıroyuk1 Yamamoto, Yasushı Adach1, Yumıko Maruyama And Yasuhisa Shınomura. Role of Matrix Metalloproteinase-7 (Matrilysin) in Human Cancer Invasion, Apoptosis, Growth, and Angiogenesis. Exp Biol Med (Maywood) January 2006 vol. 231 no. $120-27$

4. Wilson CL, Ouellette AJ, Satchell DP, Ayabe T, López-Boado YS, Stratman JL et al. Regulation of intestinal alpha-defensin activation by the metalloproteinase matrilysin in innate host defense. Science 1999;286:113-117. [PubMed: 10506557].

5. Fingleton B, Vargo-Gogola $\mathrm{T}$, Crawford HC, Matrisian LM. Matrilysin [MMP-7] expression selects for cells with reduced sensitivity to apoptosis. Neoplasia 2001;3:459-468. [PubMed: 11774028

6. Powell WC, Fingleton B, Wilson CL, Boothby M, Matrisian LM. The metalloproteinase matrilysin proteolytically generates active soluble Fas ligand and potentiates epithelial cell apoptosis. Curr Biology1999;9:1441-1447. [PubMed: 10607586].

7. Yu WH, Woessner JF Jr, McNeish JD, Stamenkovic I. CD44 anchors the assembly of matrilysin/ MMP-7 with heparin-binding epidermal growth factor precursor and ErbB4 and regulates female reproductive organ remodeling. Genes Dev 2002;16:307-323. [PubMed: 11825873].

8. Lax, A. J. and Thomas, W. How bacteria could cause cancer: one step at a time. Trends Microbiol. (2002);10, 293-299.

9. Peek, R. M., Jr and Blaser, M. J. Helicobacter pylori and gastrointestinal tract adenocarcinomas. Nat. Rev. Cancer (2002);2,28-37.

10. Selja Koskensalo, Johanna Mrena, Jan-Patrik Wiksten, Stig Nordling, Arto Kokkola, Jaana Hagström et al. MMP-7 overexpression is an worse than Japan because frequency of $G$ allele is more than Japan.

We compared cancerous and noncancerous tissues of 50 gastric cancer patients with RFLP in our study but we did not find any difference between cancerous and noncancerous tissues that will generate MMP-7$181 \mathrm{~A} / \mathrm{G}$ changes in DNA level.

\section{Acknowledgements}

This study was approved by the Ethics Committee of Ankara University Faculty of Medicine in October 25th, 2010 with decision number 17-372.

independent prognostic marker in gastric cancer Tumor Biol. (2010); 31:149-155 DOI 10.1007/s13277-010-0020-1

11. Amieva MR, El-Omar EM. Host-bacterial interactions in Helicobacter pylori infection. Gastroenterology 2008;134:306-323. [PubMed: 18166359].

12. Liu H, Merrell DS, Semino-Mora C, Goldman M, Rahman A, Mog S et al. Diet synergistically affects Helicobacter pylori-induced gastric carcinogenesis in non-human primates. Gastroenterology 2009;137:1367-1379. [PubMed: 19622359].

13. B.R. Achyut, Uday C. Ghoshal, Moorchung N, Mittal B. Transforming Growth Factor-B1 and Matrix Metalloproteinase- 7 Promoter Variants Induce Risk for Helicobacter Pylori-Associated Gastric Precancerous Lesions. DNA AND CELL BIOLOGY, 2009; 28(6) ,295-301 DOI: 10.1089= dna.2008.0842

14. Chung WC, Jung SH, Lee KM, Paik CN, Kawk JW, Jung JH et al. The detection of Helicobacter pylori cag pathogenicity islands (PAIs) and expression of matrix metalloproteinase-7 (MMP-7) in gastric epithelial dysplasia and intramucosal cancer. Gastric Cancer. 2010; Aug;13 (3):162-9. Epub 2010 Sep 5. .

15. Miyamoto $S$, Yano K, Sugimoto $S$, Ishii G, Hasebe $\mathrm{T}$, Endoh $\mathrm{Y}$ et al. Matrix metalloproteinase-7 facilitates insulin-like growth factor bioavailability through its proteinase activity on insulin-like growth factor binding protein 3. Cancer Res 2004;64: 665671 ,

16. Noe V, Fingleton $B$, Jacobs $K$, Crawford HC, Vermeulen S, Steelant W et al. Release of an invasion promoter E-cadherin fragment by matrilysin and stromelysin-1. J Cell Sci 2001;114:111-118,.

17. Pisani P, Parkin DM, Ferlay J. Estimates of the worldwide mortality from eighteen major cancers in 1985. Implications for prevention and projections of future burden. Int J Cancer 1993; 55:891.]

18. Honda M, Mori M, Ueo H, Sugimachi K, Akiyoshi T. Matrix metalloproteinase-7 expression in gastric carcinoma. Gut 1996;39:444-448. [PubMed: 8949652]. 